\title{
Politique
}

Politique

\section{Louis La Rochelle, En flagrant délit de pouvoir. Chronique des événements politiques de Maurice Duplessis à René Lévesque, Montréal, Boréal Express, 1982, 302 p.}

\section{Rénald Gravel}

Numéro 4, automne 1983

Crise et changements idéologiques

URI : https://id.erudit.org/iderudit/041006ar

DOI : https://doi.org/10.7202/041006ar

Aller au sommaire du numéro

Éditeur(s)

Société québécoise de science politique

ISSN

0711-608X (imprimé)

1918-6584 (numérique)

Découvrir la revue

Citer ce compte rendu

Gravel, R. (1983). Compte rendu de [Louis La Rochelle, En flagrant délit de pouvoir. Chronique des événements politiques de Maurice Duplessis à René Lévesque, Montréal, Boréal Express, 1982, 302 p.] Politique, (4), 169-170. https://doi.org/10.7202/041006ar d'utilisation que vous pouvez consulter en ligne.

https://apropos.erudit.org/fr/usagers/politique-dutilisation/ 
Louis La Rochelle, En flagrant délit de pouvoir. Chronique des événements politiques de Maurice Duplessis à René Lévesque, Montréal, Boréal Express, 1982, 302 p.

Comme son titre l'indique, cet ouvrage est une chronique des événements politiques de la fin de l'époque duplessiste au 
premier mandat du Parti Québécois. Précisons immédiatement que le titre est on ne peut plus approprié. L'auteur nous livre en effet, avec une minutie exceptionnelle, une chronologie des événements qui ont animé la politique au Québec depuis une vingtaine d'années. Le tout est divisé en cinq parties intitulées: la fin d'une époque, la révolution tranquille, égalité ou indépendance, le régime Bourassa et, un vrai gouvernement! La qualité première du livre réside dans la recherche du détail, notamment en ce qui concerne la période la plus récente, ce qui est sans doute dû à l'expérience de l'auteur en tant qu'animateur de la radio-télévision des débats à l'Assemblée nationale. En fait, ce qui à prime abord pourrait prendre l'allure d'une chronologie plutôt aride, devient quand on y regarde de plus près, un amalgame assez réussi de différents éléments. En effet, l'auteur a su nous livrer non seulement les faits marquants de la vie politique québécoise depuis une vingtaine d'années mais aussi les principaux dossiers qu'ont débattus les différents gouvernements. De plus, on a porté une attention particulière à la vie de parti, et au cheminement des hommes politiques qui ont laissé leur marque. Ce faisant, on nous fait prendre conscience de la passion de l'homme politique quant à l'exercice des prérogatives rattachées au pouvoir. Le tout constitue une revue somme toute fidèle de la réalité factuelle. Précisons toutefois que le contenu nous est livré de façon saccadée, sans transition, principale contrainte posée par ce type d'ouvrage. Enfin, mentionnons qu'en délaissant volontairement semble-t-il, l'analyse politique structurée, l'auteur a lui-même fixé les limites et la portée de sa démarche. Il s'agit là d'une moindre critique, dans la mesure où les couleurs étaient annoncées dès le dépat.

Rénald Gravel

Université Laval 